\title{
Relationship between gibberellic acid and growth parameters in developing seed and pod of pigeon pea
}

\author{
Rita S. Chudasama* and Vrinda S. Thaker \\ Department of Biosciences, Saurashtra University, Rajkot 360 005, India. *Corresponding author: \\ vsthakar@hotmail.com
}

Received: 19 February 2007; Returned for revision: 27 April 2007; Accepted: 04 June 2007

\begin{abstract}
Changes in endogenous gibberellic acid (GA) levels were determined in developing seeds and pods of pigeon pea (Cajanus cajan). Antibodies against $\mathrm{GA}_{3}$ were raised in rabbits and indirect ELISA developed to estimate GA level. Two varieties, black seeded variety $\left(\mathrm{V}_{1}\right)$ and B.D. $\mathrm{N}_{2}\left(\mathrm{~V}_{2}\right)$, were selected on the basis of their seed index value. The pod length and number of seeds per pod were significantly different for the two varieties. Dry weight, water content (WC), rate of water accumulation, rate of dry matter accumulation (DMA), and GA content in pod and seed were all larger in $\mathrm{V}_{1}$ than in $\mathrm{V}_{2}$. In both varieties, higher GA content was observed during cell elongation and DMA phases, respective to their varietal differences in growth traits. Relationships between WC and rate of DMA, and WC and GA differed significantly between the two varieties. The results suggest a role of GA and WC in sink-size development in both varieties studied. Key words: Cajanus cajan, dry matter accumulation, endogenous gibberellic acid, seed development, water content
\end{abstract}

Relações entre o ácido giberélico e parâmetros de crescimento em sementes e vagens em desenvolvimento de feijãoguandu: Foram estudadas alterações nos níveis endógenos do ácido giberélico (GA) em sementes e vagens em desenvolvimento de feijão-guandu (Cajanus cajan). Anticorpos contra $\mathrm{GA}_{3}$ foram obtidos a partir de coelhos; um método de ELISA indireto foi desenvolvido para estimar o nível endógeno de GA. Duas variedades, variedade de semente preta $\left(\mathrm{V}_{1}\right)$ e B.D. $N_{2}\left(V_{2}\right)$, foram selecionadas tendo-se por base seus valores de índice de número de sementes. O comprimento da vagem e o número de sementes por vagem foram significativamente diferentes nas duas variedades. A massa seca, o conteúdo de água (CA), a taxa de acúmulo de água, a taxa de acúmulo de massa seca (AMS) e o conteúdo de GA nas sementes e nas vagens foram maiores em $\mathrm{V}_{1}$ que em $\mathrm{V}_{2}$. Em ambas as variedades, maiores conteúdos de GA foram observadas durante as fases de elongação celular e AMS, em conformidade com as diferenças de crescimento entre as duas variedades. Relações entre CA, taxa de AMS, CA e GA diferiram significativamente entre as duas variedades. Os resultados sugerem que GA e CA são importantes para o desenvolvimento do tamanho do dreno nas duas variedades estudadas.

Palavras-chave: ácido giberélico endógeno, Cajanus cajan, acúmulo de massa seca, conteúdo de água, desenvolvimento de semente

\section{INTRODUCTION}

The gibberellins (GAs) are a large family of tetracyclic diterpenoid plant growth substances. The function of GA as a hormone in regulating plant growth was known as early as the 1950s (Brian and Hemming, 1955; Vlitos and
Meudt, 1957). Gibberellins are associated with various plant growth and development processes such as seed germination, stem and hypocotyl elongation, leaf expansion, floral initiation, floral organ development, fruit development and induction of some hydrolytic

Abbreviations: DAA - days after anthesis; DMA - dry matter accumulation; ELISA - enzyme-linked immunosorbent assay; PBS phosphate buffer saline; PBS-T - phosphate buffer saline with Tween-20; $\mathrm{V}_{1}$ - variety $1 ; \mathrm{V}_{2}$ - variety 2 ; WAR - water accumulation rate; WC - water content 
enzymes in the aleurone of cereal grains (Matsuoka, 2003). Hooley (1994) has proposed that the types of responses of plant cells and tissues to GAs can be classified into three categories: cell growth in vegetative tissues, seed reserve mobilization by aleurone cells, and flower and fruit development.

Fruit size is considered to be one of the important characteristics in new cultivar selection. Gibberellins control fruit development in various ways and at different developmental stages. Fruit development is a complex and tightly regulated process. Growing fruits are very active metabolically and act as strong sinks for nutrients with hormones possibly modulating the process (Brenner and Cheikh, 1995). Plant hormones play a significant role in the process that leads to mature fruit and viable mature seed (Nitsch, 1970). Exogenous applications of various hormones at different stages of fruit development and endogenous quantifications have highlighted their importance during fruit development.

The development of a fruit can be separated into phases that include pre-pollination, pollination, fertilization and fruit set, post fruit set, ripening and senescence. The successful fertilization of the ovule is followed by cell division and cell expansion resulting in the growth of the fruit. Gibberellins are known to influence both cell division and cell enlargement (Adams et al., 1975; Kamijima, 1981). Previous studies have suggested that these GA-mediated growth responses are regulated in part by the modulation of cellular GA concentrations and by altering the ability of cells to respond to this hormone (Richards et al., 2001). Seeds, a rich source of many hormones (Crane, 1969), are known to be essential for normal development of fruits; the size and shape of many fruits being determined by seed number and distribution. For many species, $\mathrm{GA}_{3}$ produced by developing seeds stimulates the growth and maturation of that fruit. Studies on endogenous GAs and GA metabolism in developing and mature seeds and grain have revealed that extremely large amounts of GAs accumulate during dry matter accumulation (DMA) (Pharis and King, 1985). Viable seeds are an important sink signal for driving fruit development and seed-fill duration often correlates with yield (Egli, 1994). Thus for high yield it is important to maintain a steady sink activity throughout the seed-filling period (Hanson, 1991; Jenner et al., 1991).
The Leguminosae are second to cereal crops in agricultural importance based on area harvested and total production. Studies on physiological roles of GAs in seeds of dicotyledonous plants have shown that developing seeds of Leguminosae contain large amounts of GAs (Nakayama et al., 2002). Pigeon pea is an important pulse crop of India. It is a rich source of proteins, carbohydrates, and certain minerals (Salunkhe et al., 1986) and used for food, feed, and fuel. Although hormonal regulation of fruit development has long been studied in many legumes, to date there is no report on endogenous regulation of GA in pigeon pea fruit development. This study aimed to evaluate the role of GA in seed development in pigeon pea. Endogenous levels of GA from the seed and pod were estimated by indirect ELISA, during the entire period of growth and development. To understand the probable role of GA, two varieties, distinct in their growth parameters, were selected.

\section{MATERIAL AND METHODS}

Plant material and growth conditions: Certified seeds of two varieties of pigeon pea [Cajanus cajan (L.) Millsp], $\mathrm{V}_{1}$ (Black seeded) and $\mathrm{V}_{2}$ (B.D. $\mathrm{N}_{2}$ ), were selected for the study and purchased from the commercial market at Rajkot, India. The growth experiment of pigeon pea was performed during the period from July 2005 to February 2006. Seeds of both varieties were imbibed in water for $3 \mathrm{~h}$ and sown $2 \mathrm{~cm}$ deep in black cotton soil at the botanical garden of Saurashtra University, Rajkot (20 $17^{\circ} \mathrm{N}$, 7049’E), India. Standard agricultural practices, e.g. irrigation, application of fertilizers and insecticides, were maintained throughout the crop growth to maximize the yield. Fertilizer (NPK) was applied to the soil before planting while pesticide was given twice during the flowering period. Irrigation practices were followed on alternate days throughout the growth period. Flowers were tagged on the day of anthesis and numbers of flowers were recorded every day. Pods of equal size were harvested at 3-d intervals for growth analysis and estimation of endogenous GA.

Fresh and dry weight measurements: For the measurement of fresh and dry weights, pods were harvested at 3-d intervals, from $0 \mathrm{~d}$ up to $54 \mathrm{~d}$ after anthesis (DAA), when 
maturation was reached. Seeds were separated from the pods. Pod length and number of seeds per pod were measured. Pods and seeds were weighed before and after oven drying at $80^{\circ} \mathrm{C}$ for $5 \mathrm{~d}$ to a constant weight. Water content (WC) was determined by differences in fresh and dry weights. Data were taken in triplicate and the mean fresh weight, dry weight and WC were calculated with their standard deviations.

Raising of antibodies against $G_{3}$ : To raise antibodies against $\mathrm{GA}_{3}$, a $\mathrm{GA}_{3}$-BSA conjugate was prepared as described by Weiler and Wieczorek (1981). Such a conjugate was mixed with an equal volume of Freund's complete adjuvant and injected into two rabbits. Antigen is more immunogenic when presented in an insoluble form with an adjuvant. After five intramuscular injections at 15-d intervals, booster doses were given periodically to raise the antibody titer. Rabbits were bled periodically when about 10-15 mL of blood was collected. The blood sample was incubated at $37^{\circ} \mathrm{C}$ for $1 \mathrm{~h}$ and serum was separated. $\gamma$-Immunoglobulin ( $\mathrm{IgG}$ ) was collected by passing the serum through DEAE cellulose preequilibrated with $0.01 \mathrm{M}$ phosphate buffer ( $\mathrm{pH}$ 8.0). The purified IgG was concentrated to the original volume of serum taken, in $0.01 \mathrm{M}$ phosphate buffer ( $\mathrm{pH}$ 8.0). Purified antibodies were stored in glass vials at $-20^{\circ} \mathrm{C}$ and used for estimation after appropriate dilution.

Extraction of GA from seeds and pods: Seeds and pods of different ages were crushed with liquid nitrogen. From the frozen samples $500 \mathrm{mg}$ of powder was mixed with $5 \mathrm{~mL}$ of $80 \%$ methanol containing $100 \mathrm{mg}$ ascorbic acid as antioxidant. The mixture was incubated for $48 \mathrm{~h}$ and centrifuged at 10,000 $\mathrm{g}$ for $10 \mathrm{~min}$. The supernatant was collected and pellet washed twice with $80 \%$ methanol. The pooled supernatant was collected and left to evaporate. The final volume of the samples $(10 \mathrm{~mL})$ was prepared with phosphate buffer saline $(\mathrm{pH}$ 7.2) and used for the estimation of GA.

Estimation of GA content: Endogenous levels of GA were estimated by a comparatively more sensitive and specific technique, i.e. indirect ELISA (Gokani and Thaker, 2002). $\mathrm{GA}_{3}$-casein conjugate $(300 \mu \mathrm{L})$ was coated on the ELISA plate and incubated overnight at $4{ }^{\circ} \mathrm{C}$ followed by washing with phosphate buffer saline containing Tween-20 (PBS$\mathrm{T})$. The next step involved the blocking of free protein- binding sites of the well with egg albumin after incubation for $1 \mathrm{~h}$ at $37^{\circ} \mathrm{C}$, followed by washing the plate three times with PBS-T. Then, antibodies against $\mathrm{GA}_{3}$ mixed with samples were coated and incubated for $3 \mathrm{~h}$ at $37^{\circ} \mathrm{C}$. Finally, the plate was coated with anti-Rabbit IgG tagged with peroxidase and the color developed using o-phenylene diamine as substrate. The reaction was terminated by addition of $6 \mathrm{~N}$ sulfuric acid $(50 \mu \mathrm{L})$. After each coating, the ELISA plate was washed thoroughly with phosphate buffer saline (PBS) containing 0.05\% Tween-20.

Relative binding values were calculated as B/Bo, where $\mathrm{B}$ and $\mathrm{Bo}$ are the values of absorbance with (B) and without (Bo) internal hormone standard or sample, respectively. A standard curve was prepared in the range 50-500 ng (see Figure 6) for each plate and values falling within the curve were taken. To test the sensitivity of the assay, each sample was mixed with a known amount of $\mathrm{GA}_{3}(200 \mathrm{ng})$ as an internal standard before reacting with the antibodies.

Data were taken in triplicate and the mean value of three replicates was calculated. Endogenous levels of GA in developing seed and pods were expressed as $\mu \mathrm{g} \mathrm{GA}_{3}$ equivalent seed ${ }^{-1}$ and $\mu \mathrm{g} \mathrm{GA}_{3}$ equivalent $\operatorname{pod}^{-1} \mathrm{FW}$, respectively.

Statistical analysis: The statistical significance between means of endogenous GA and growth parameters of the seed and pod of two varieties was analyzed using analysis of variance. Correlation coefficients were determined between growth parameters (i.e. dry weight, WC, rate of DMA and WAR) and endogenous GA during the entire period of seed and pod development. Values of $\mathrm{P} \leq 0.05$ were considered for the data interpretation.

\section{RESULTS}

Growth analysis: Seed size on a weight basis was larger in $\mathrm{V}_{1}$ than $\mathrm{V}_{2}$. In $\mathrm{V}_{1}$, dry weight per seed increased up to 45 DAA and then stabilized at later stages. Maximum dry weight was $187 \mathrm{mg} \mathrm{seed}^{-1}$ at 54 DAA (Figure 1A). Water content per seed increased up to 39 DAA, stabilized up to 45 DAA and then declined at later stages. Maximum WC was $268 \mathrm{mg} \mathrm{seed}^{-1}$ at 45 DAA (Figure 1B). In V2, dry weight of seed increased up to 45 DAA, stabilized at later stages and peaked at 54 DAA (116 mg). Water content per seed increased gradually up to 36 DAA, stabilized up to 
45 DAA and declined at later stages. Maximum WC was $153 \mathrm{mg} \mathrm{seed}^{-1}$ at 45 DAA (Figure 1B). The maximum rate of DMA was observed at $39 \mathrm{DAA}\left(9.3 \mathrm{mg} \mathrm{d}^{-1}\right)$ in $\mathrm{V}_{1}$ and at $36 \mathrm{DAA}\left(5.1 \mathrm{mg} \mathrm{d}^{-1}\right)$ in $\mathrm{V}_{2}$ whereas the maximum water accumulation rate (WAR) was observed at $30 \mathrm{DAA}$ $\left(12.99 \mathrm{mg} \mathrm{d}^{-1}\right)$ in $\mathrm{V}_{1}$ and at 27 DAA $\left(7.01 \mathrm{mg} \mathrm{d}^{-1}\right)$ in $\mathrm{V}_{2}$ (Figure 2A, B).

The number of seeds per pod was 6-7 in $\mathrm{V}_{1}$ and 4-5 in $\mathrm{V}_{2}$; thus pod length was larger in $\mathrm{V}_{1}(11-12 \mathrm{~cm})$ than in $\mathrm{V}_{2}$ (5-6 cm). In $\mathrm{V}_{1}$, pod length increased up to $27 \mathrm{DAA}$ and stabilized at later stages. In $\mathrm{V}_{1}$ the maximum pod length was $11 \mathrm{~cm}$ at $27 \mathrm{DAA}$ and the maximum rate of length increase was $0.672 \mathrm{~cm} \mathrm{~d}^{-1}$ at 15 DAA (Figures 3A and 4A). In $\mathrm{V}_{2}$, pod length increased up to 21 DAA and stabilized at later stages. In $\mathrm{V}_{2}$ the maximum pod length was $6.95 \mathrm{~cm}$ at 42 DAA whereas the maximum rate of length increase was $0.471 \mathrm{~cm} \mathrm{~d}^{-1}$ at 9 DAA (Figures $3 \mathrm{~A}$ and $4 \mathrm{~B}$ ).
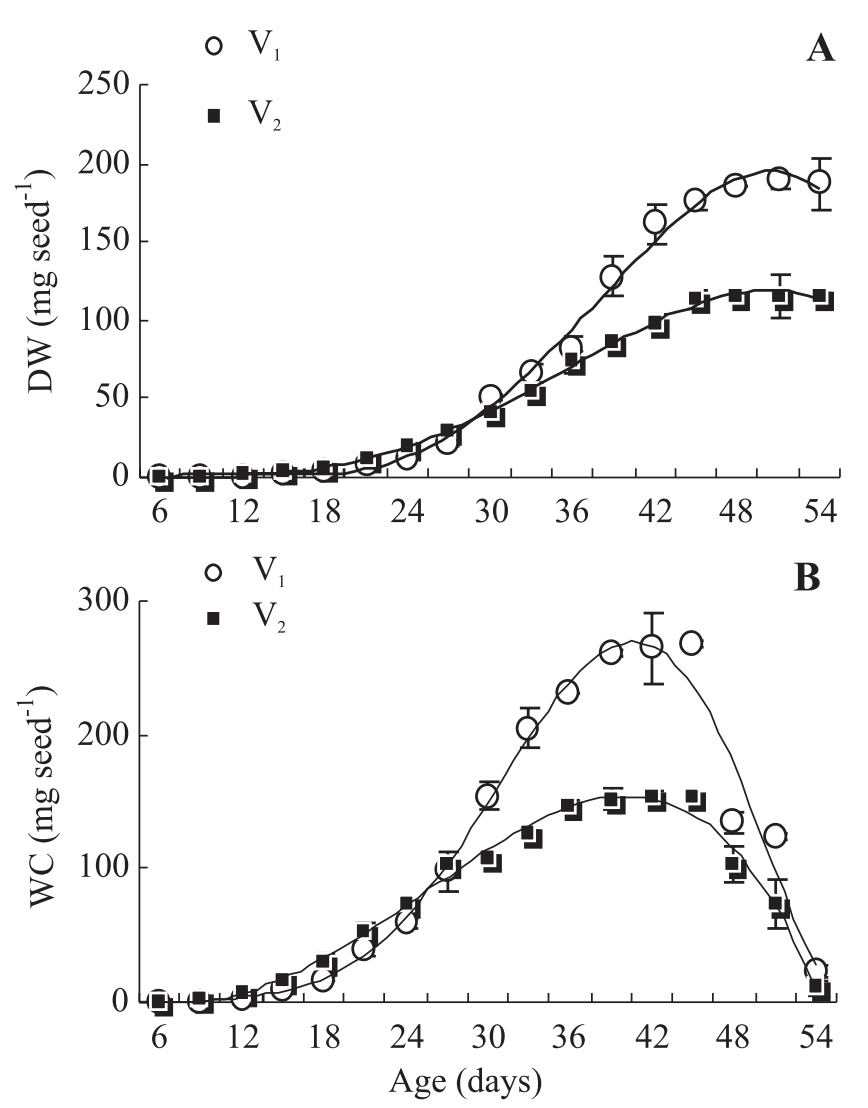

Figure 1. Changes with age in dry weight (DW) (A) and water content (WC) (B) of seeds of two pigeon pea varieties, $V_{1}$ and $V_{2}$. Each data point is the mean of nine replicates. Vertical bars represent SD; when not shown, the SD was smaller than the symbols.
In $\mathrm{V}_{1}$ the pod dry weight increased gradually up to 36 DAA, stabilized at later stages and the maximum value (591 mg) was reached at 45 DAA (Figure 5A). Water content per pod increased up to $27 \mathrm{DAA}$, stabilized up to 42 DAA and then declined at later stages. Maximum WC per pod was $1254 \mathrm{mg}$ at $30 \mathrm{DAA}$ (Figure 5B). In $\mathrm{V}_{2}$ the pod dry weight increased gradually up to 42 DAA, stabilized at later stages and reached its maximum value $(201.7 \mathrm{mg})$ at 42 DAA (Figure 5A). Water content per pod increased gradually up to 27 DAA, stabilized up to 42 DAA and declined at later stages. The maximum value of water content was $339 \mathrm{mg}$ at 39 DAA (Figure 5B).

The maximum rate of pod DMA was $28.8 \mathrm{mg} \mathrm{d}^{-1}$ at 21 DAA in $\mathrm{V}_{1}$ and $6.9 \mathrm{mg} \mathrm{d}^{-1}$ at $18 \mathrm{DAA}$ in $\mathrm{V}_{2}$ (Figure $3 \mathrm{~B}$ ). The maximum WAR was $77.2 \mathrm{mg} \mathrm{d}^{-1}$ at 18 DAA in $\mathrm{V}_{1}$ and 21.3 $\mathrm{mg} \mathrm{d}^{-1}$ at 15 DAA in $\mathrm{V}_{2}$ (Figure 4 ).
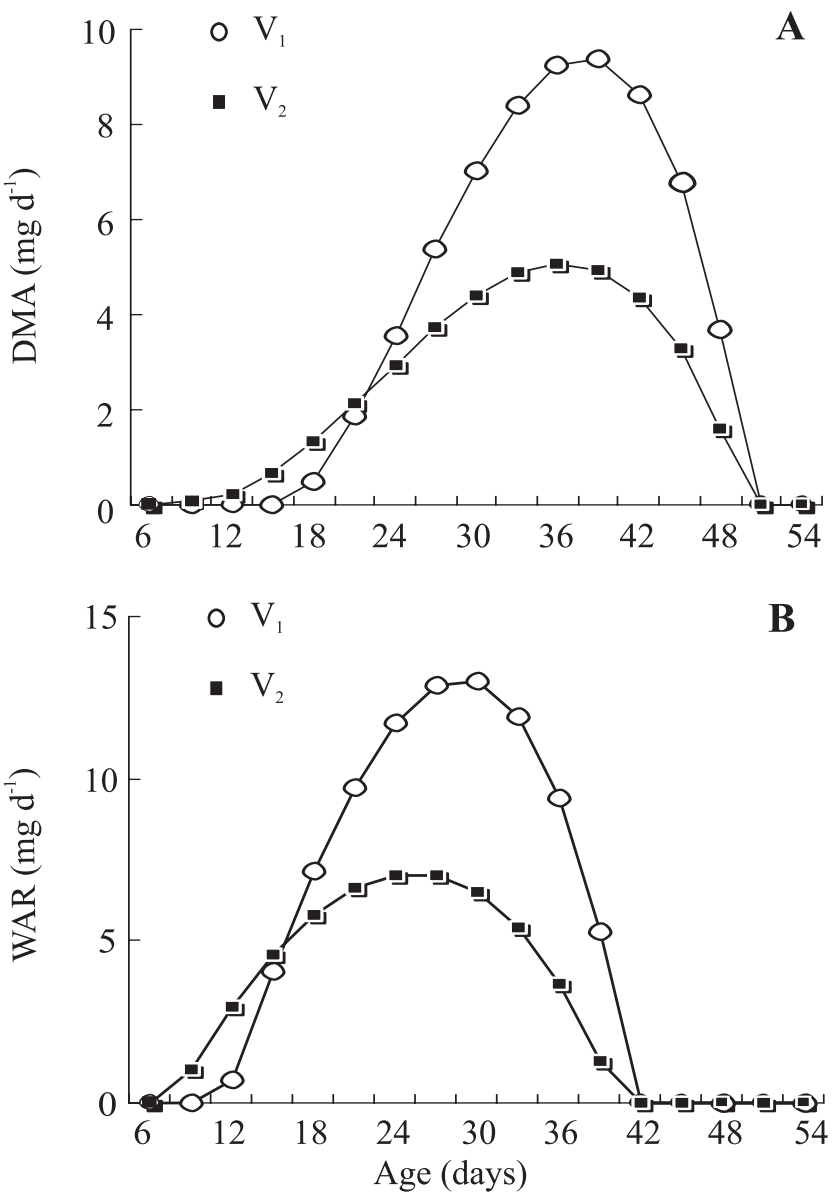

Figure 2. Changes in rate of dry matter accumulation rate (DMA) (A) and water accumulation rate (WAR) (B) in developing seeds of two pigeon pea varieties, $V_{1}$ and $V_{2}$. 

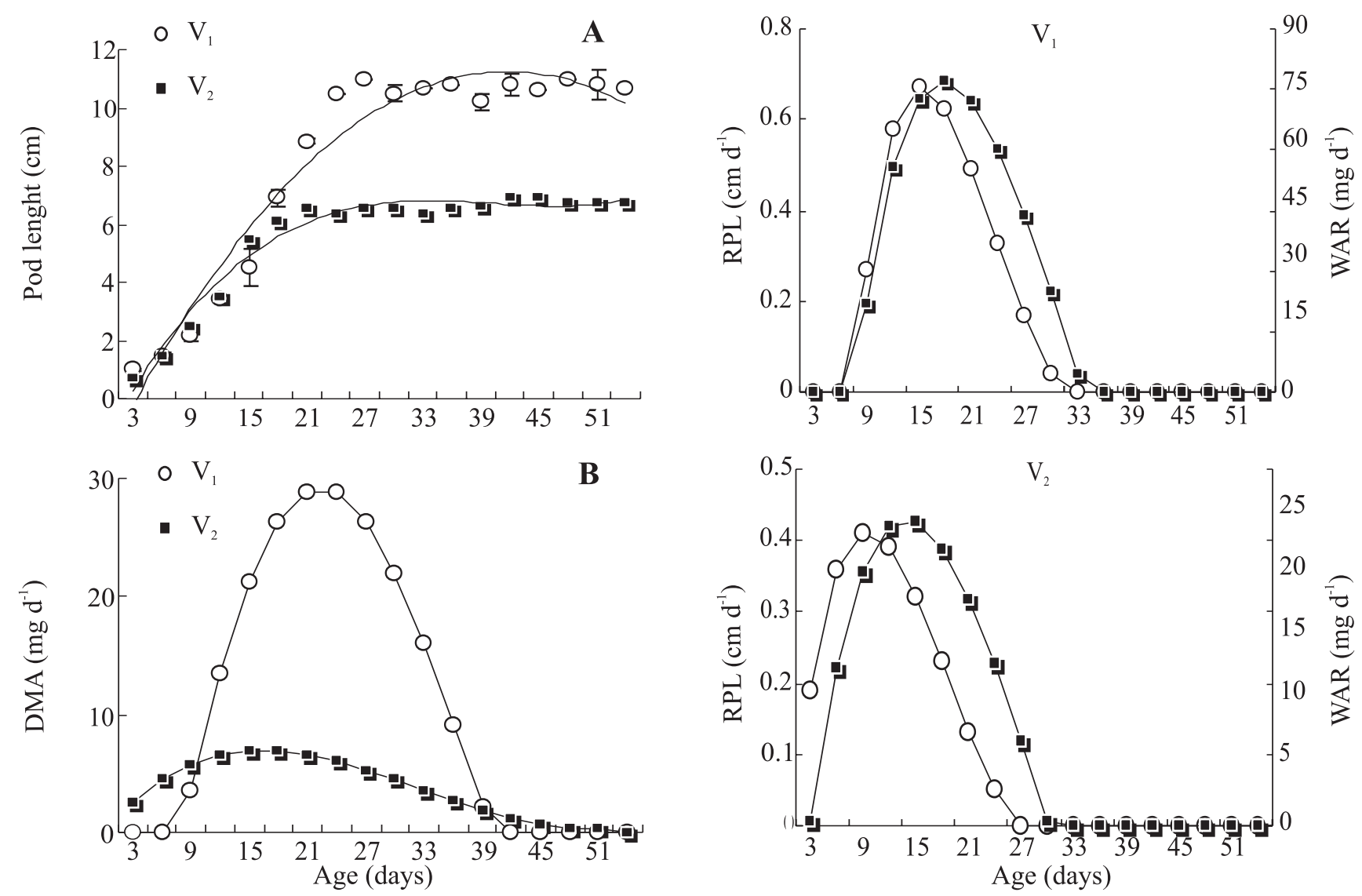

Figure 3. Changes in pod length (A) and dry matter accumulation rate (DMA) (B) in developing pods of two pigeon pea varieties, $\mathrm{V}_{1}$ and $\mathrm{V}_{2}$. Each data point is the mean of nine replicates. Vertical bars represent SD; when not shown, the SD was smaller than the symbols.

Changes in seed GA content: Changes in B/Bo against $\mathrm{GA}_{3}$ concentration is presented in Figure 6. It showed a linear relationship from 50 to $500 \mathrm{ng}$. This antibody was produced against $\mathrm{GA}_{3}$ and its cross reactivity was not tested against other naturally available GAs and hence estimated endogenous levels are referred to as GA throughout in this work. In $\mathrm{V}_{1}$, negligible values of GA were recorded during early stages of seed development (up to 18 DAA). From 24 DAA the GA content increased gradually and a peak $\left(40.3 \mu \mathrm{g} \mathrm{seed}^{-1}\right)$ was observed at 45 DAA followed by a decrease at later periods of seed development. In 54-DAA-old mature seed, the value of GA was $11.1 \mu \mathrm{g}$ (Figure $7 \mathrm{~A}$ ). In $\mathrm{V}_{2}$ the level of GA increased gradually with seed development and reached a peak $\left(15.8 \mu \mathrm{g} \mathrm{seed}^{-1}\right)$ at $45 \mathrm{DAA}$, followed by a gradual

Figure 4. Changes in rate of pod length increase (RLP, open symbols) and water accumulation rate (WAR, solid symbols) in developing pods of two pigeon pea varieties, $\mathrm{V}_{1}$ and $\mathrm{V}_{2}$. Each data point is the mean of nine replicates. Vertical bars represent SD.

decrease at later stages (Figure 7A).

At later stages of seed development the same pattern of GA level was observed. However, the GA content remained three times higher in $\mathrm{V}_{1}$. A difference in GA content was also observed during the initial stages; up to 18 DAA the value of GA was $2.27 \mu \mathrm{g} \mathrm{seed}^{-1}$ in $\mathrm{V}_{2}$, whereas in $\mathrm{V}_{1}$ it was negligible.

Changes in pod GA content: In $\mathrm{V}_{1}$ the pod GA content increased gradually with age and peaked at 30 DAA $(153.1 \mu \mathrm{g})$. Later, it decreased gradually and at 54 DAA the GA level was $35.3 \mu \mathrm{g}$ (Figure 7B). In $\mathrm{V}_{2}$ the GA level increased gradually up to 39 DAA and at later stages it showed a declining trend. The maximum value was 43.6 $\mu$ g at 39 DAA (Figure 7B). 


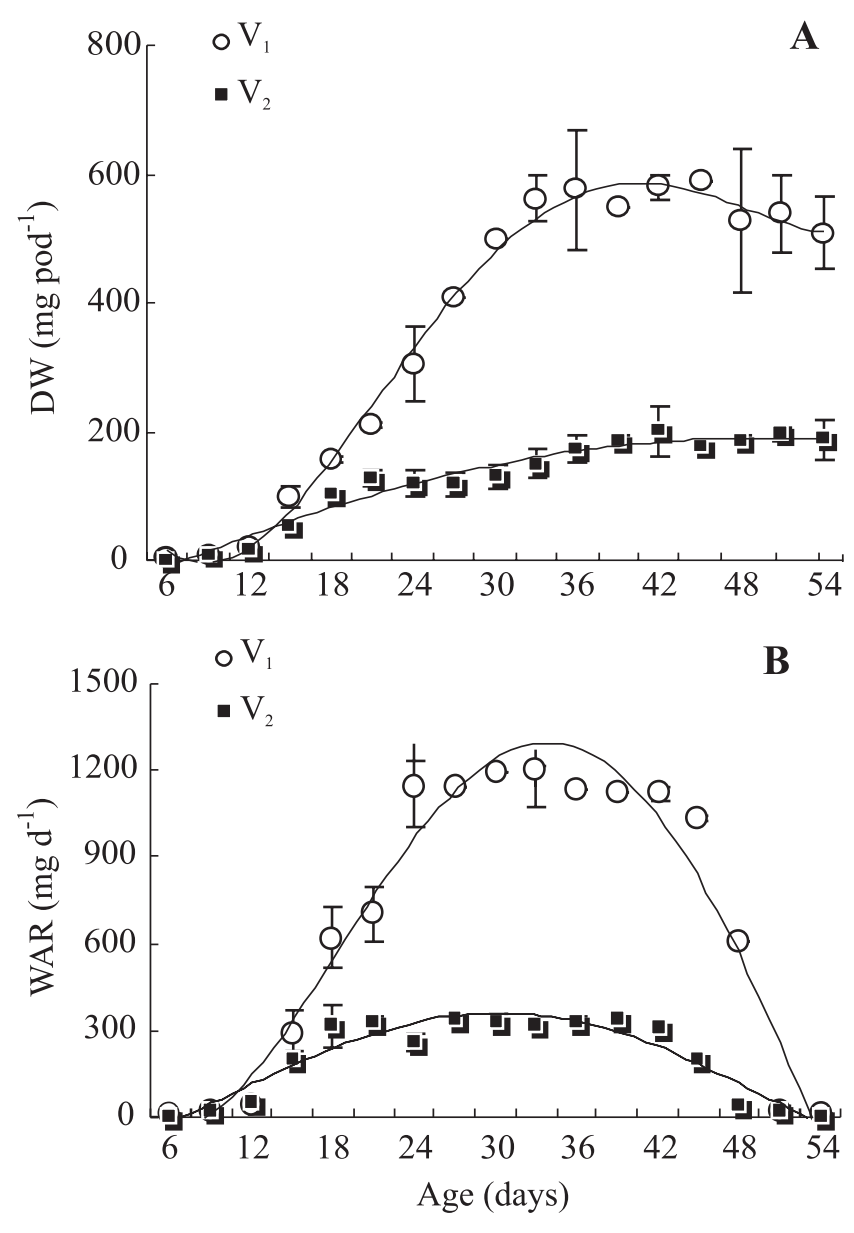

Figure 5. Changes in pod dry weight (DW) (A) and pod water content (WC) (B) of two pigeon pea varieties, $\mathrm{V}_{1}$ and $\mathrm{V}_{2}$. Each data point is the mean of nine replicates. Vertical bars represent SD; when not shown, the SD was smaller than the symbols.

\section{DISCUSSION}

Data on dry matter and WC were fitted to an appropriate polynomial equation. The rate of DMA and WAR were obtained from the fitted curve. On the basis of growth analysis, seed development in the two varieties can be divided into four distinct stages. The initial lag phase of DMA (0-15 DAA) is considered as the cell division phase (i), rapid water uptake (12-36 DAA in $\mathrm{V}_{1}$ and 9-36 DAA in $\mathrm{V}_{2}$ ) as the cell elongation phase (ii), rapid rate of DMA (21-42 DAA in $\mathrm{V}_{1}$ and 18-39 DAA in $\mathrm{V}_{2}$ ) as the DMA phase (iii), and stabilization of DMA (42-54 DAA in $\mathrm{V}_{1}$ and 39-54 DAA in $\mathrm{V}_{2}$ ) as the maturation phase (iv). Overlap between these phases was observed in both the varieties studied (Figures 1 and 2). Similar growth phases

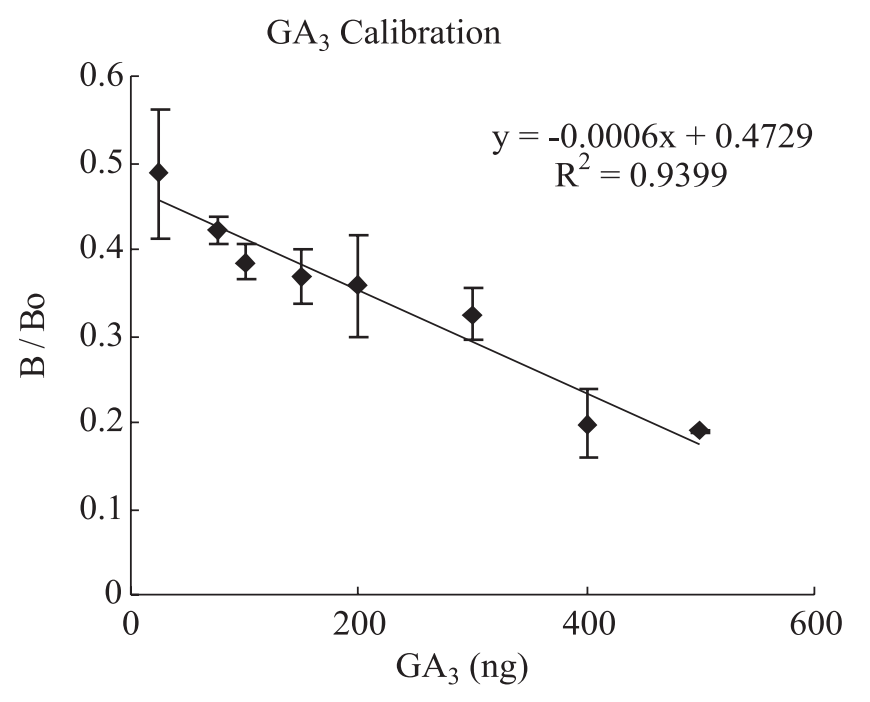

Figure 6. Calibration curve of standard gibberellic acid $\left(\mathrm{GA}_{3}\right)$ in the range 50-500 ng. B and Bo are the values of absorbance with (B) and without (Bo) internal hormone standard or sample, respectively. Each data point is the mean of nine replicates. Vertical bars represent SD.

are described for seed development in cotton (Thaker et al., 1992; Rabdia et al., 1999).

The pattern of endogenous levels of GA was similar in developing seeds of both varieties and showed significant differences. On the basis of seed growth phases, in $V_{1}$ seed the endogenous GA level increased rapidly during the cell elongation phase until the maximum value for DMA was reached. The maximum level of GA was observed at $45 \mathrm{DAA}$, coinciding with the peak of WC in seed. Similarly in $\mathrm{V}_{2}$, the level of GA increased gradually up to 45 DAA coinciding with maximum WC (Figure 7A).

It is well documented that GA plays a significant role in seed development in various plant species. Gibberellins have been suggested to be involved in early stages of seed development in pea (Swain et al., 1997) and Phaseolus (Yeung and Meinke, 1993). In a number of plant species, early seed growth was correlated with an increase in bioactive GAs (Pharis and King, 1985; Rock and Quatrano, 1995). It has been proposed that GAs are closely related to cell division and cell enlargement during fruit development in Japanese peer (Zhang et al., 2005). Exogenous application of GA increased seed weight and delayed seed dehydration, suggesting a role of GA in later stages of fruit and seed development (Groot et al., 1987). 

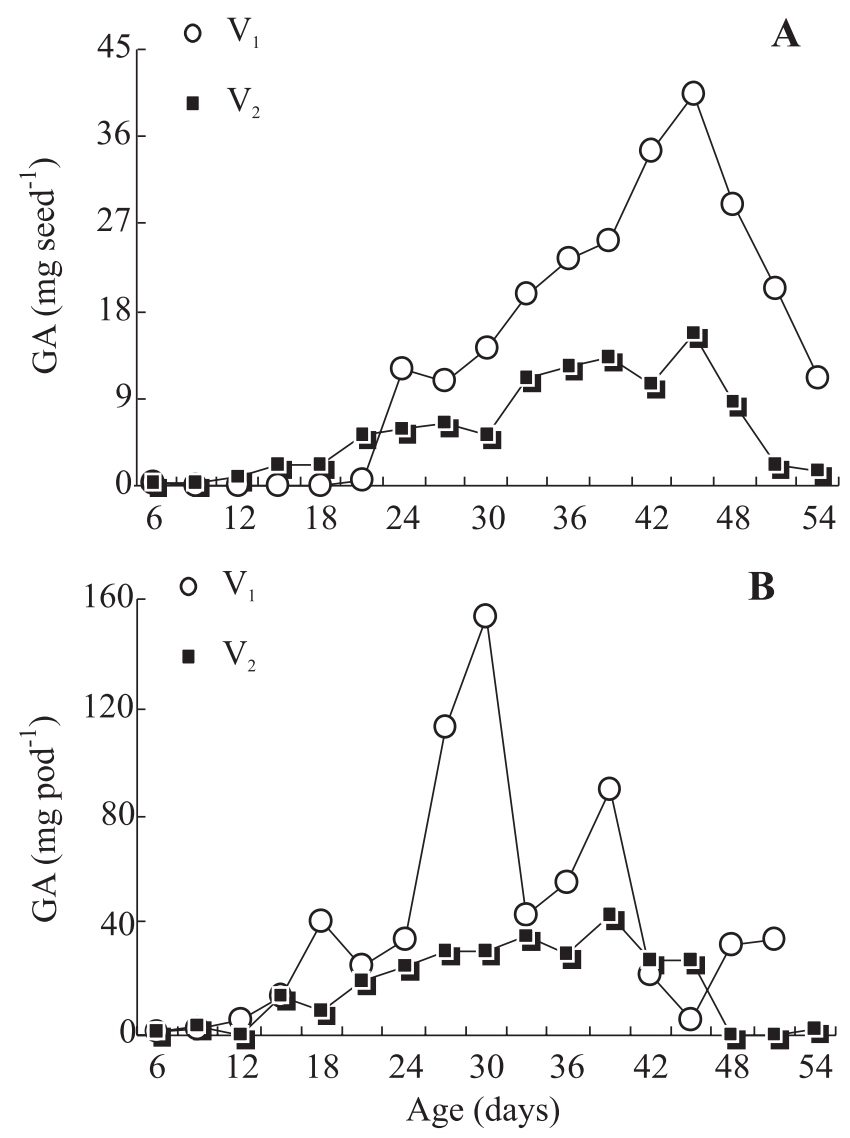

Figure 7. Changes in endogenous content of gibberellic acid $\left(\mathrm{GA}_{3}\right)$ in seeds $(\mathbf{A})$ and pods $(\mathbf{B})$ of two pigeon pea varieties, $V_{1}$ and $V_{2}$. Each data point is the mean of three replicates. Standard deviations were smaller than the symbols.

In $\mathrm{V}_{1}$ seed dry weight and WC showed significant correlation with endogenous gibberellic acid (Table 1). In $\mathrm{V}_{2}$ seed, WC showed significant correlation with endogenous GA, while dry weight was less significant. These results suggest that the endogenous GA level increased the level of WC and thus enhanced cell elongation. Similarly it was observed in $\mathrm{V}_{1}$ seed that the GA concentration doubled during DMA and the cell maturation phase (Figure 7A). In both seeds, WC showed close correlation with GA suggesting that higher GA leads to a greater uptake of water. Nanda and Dhindsa (1968) suggested that enhanced elongation of internodes is a consequence of enhanced mobilization of food reserves by $\mathrm{GA}_{3}$. Similarly, increasing the concentration of $\mathrm{GA}_{3}$ in alfalfa and brome grass increased the growth and total yield (Bidlack and Buxton, 1995).
Table 1. Correlations among endogenous gibberellic acid (GA) contents (in seeds and pods) and dry weight, water content and rate of dry matter accumulation (DMA) in two pigeon pea varieties. $*$ Statistically significant $(P<$ $0.05)$; **Statistically significant $(P<0.01)$; ***Statistically significant $(P<0.001)$.

\begin{tabular}{lcclcc}
\hline & \multicolumn{2}{c}{$\mathrm{GA}$ (seed) } & & \multicolumn{2}{c}{$\mathrm{GA}$ (pod) } \\
\cline { 2 - 3 } \cline { 5 - 6 } & $\mathrm{V}_{1}$ & $\mathrm{~V}_{2}$ & & $\mathrm{~V}_{1}$ & $\mathrm{~V}_{2}$ \\
\hline Dry weight & $0.81^{* * *}$ & $0.55^{*}$ & & $0.42^{*}$ & $0.42^{*}$ \\
Water content & $0.91^{* * *}$ & $0.93^{* * *}$ & & $0.60^{* *}$ & $0.86^{* * *}$ \\
Rate of DMA & $0.69^{* * *}$ & $0.83^{* * *}$ & & 0.34 & -0.03 \\
\hline
\end{tabular}

In the present study, at the cell division and elongation phases, the difference in dry weight and WC was not statistically significant between $\mathrm{V}_{1}$ and $\mathrm{V}_{2}$, in contrast to the situation at later stages (from 30 DAA to 54 DAA) both the rate of DMA and WAR in seeds differed significantly between the two varieties (Figure 2). A close correlation was observed between WC and the rate of DMA in both varieties (Table 1), suggesting a role of WC in DMA. The rate of DMA was double in $\mathrm{V}_{1}$, as also was the case of WAR (Figure 2). These results suggest that a high rate of water uptake increased the rate of DMA in seeds and hence both seeds were different in weight. Similarly, the rate of pod length showed close correlation with rate of WC (Figure 4), suggesting that increase in length was associated with higher water uptake that in turn would allow enhanced DMA. In fact, an important role of WC has been reported for various plant species. The effect of water stress decreased the growth and elongation of internodes in Tectona grandis (Rajendrudu and Naidu, 1997). Villela (1998) suggested that during seed development, WC is typically high after fertilization and decreases as physiological maturity occurs. In legume seed development, due to higher water uptake, transgenic cotyledons take up more amino acids, leading to higher protein content (Borisjuk et al., 2003).

In $\mathrm{V}_{1}$ pod, the endogenous level of GA increased gradually with pod age. Maximum GA was present at 30 DAA, when the pod attained maximum WC. Gibberellins enhance longitudinal growth in the shoot and increase water uptake (Banyal and Rai, 1983). This is mainly due to a GA-mediated increase in cell expansion. Here, water content of the pod showed significant correlation with GA, thus suggesting the important role of GA in pod 
development. In $\mathrm{V}_{2}$ the maximum GA value was observed at 39 DAA, when the pod also attained maximum WC. A similar correlation between the endogenous level of GA and WC per pod was observed in $\mathrm{V}_{2}$ but the level of GA remained lower suggesting that low GA may reduce water uptake during pod development. Similarly a difference in rate of fiber length and WC was observed in three cotton cultivars (Rabadia et al., 1999). In legume plants, pod development is characterized by active cell division in the young ovule and is marked by rapid pod expansion; both processes are very sensitive to water uptake. Inglese et al. (1998) suggested that high levels of GAs produced by the fruits at the time of anthesis/fertilization induce physiological changes in the maternal tissue that ensure the supply of water and dry matter. Mahouachi et al. (2005) found that the endogenous level of GA is closely associated with water availability during citrus fruit development. Water stress usually reduces fruit yield (van Iersel et al., 1994; Nerd and Mizrahi 1995; Wang and Evangelou, 1995), leading, in some cases, to the abscission of immature fruit (Wang and Evangelou, 1995).

Fruit development requires a major investment of carbon and water (Galen et al., 1999). Photosynthate supply plays an important role in controlling crop reproductive development under well-watered conditions. Pods are part of a source-sink pathway that can produce photosynthates and deliver nutrients to the seeds. In this study, pods are larger in $\mathrm{V}_{1}$ and therefore number of seeds per pod is also greater. Higher amounts of GA in larger pods and seed may increase uptake of water in the whole fruit. It is proposed that endogenous GA and WC of seed and pod play an important role in increasing fruit size of pigeon pea.

\section{REFERENCES}

Adams PA, Montague MJ, Tepfer M, Rayle DL, Ikuma H, Kaufman PB (1975) Effect of gibberellic acid on the plasticity and elasticity of Avena stem segments. Plant Physiol. 56:757-760.

Banyal S, Rai VK (1983) Reversal of osmotic stress effects by gibberellic acid in Brassica campestris. Recovery of hypocotyl growth, protein and RNA levels in the presence of GA. Physiol. Plant. 59:111-114.

Bidlack JE, Buxton DR (1995) Chemical regulation of growth, yield, and digestibility of alfalfa and smooth bromegrass. J. Plant Growth Regul. 14:1-7.
Borisjuk L, Rolletschek H, Wobus U, Weber H (2003) Differentiation of legume cotyledons as related to metabolic gradients and assimilate transport into seeds. J. Exp. Bot. 54:503-512.

Brenner ML, Cheikh N (1995) The role of hormones in photosynthate partitioning and seed filling. In: Davies PJ (ed), Plant Hormones: Physiology, Biochemistry and Molecular Biology, pp.649-670. Kluwer Academic Publishers, Dordrecht.

Brian PW, Hemmings HG (1955) The effects of gibberellic acid on shoot growth of pea seedlings. Physiol. Plant. 8:669-681.

Crane JC (1969) The role of hormones in fruit set and development. Hort. Sci. 4:108-111.

Egli DB (1994) Seed growth and development. In: Boote KJ, Bennet JM, Sinclair T, Paulsen GM (eds), Physiology and Determination of Crop Yield, pp.127-147. Crop Science Society of America, Madison.

Galen C, Sherry RA, Carroll AB (1999) Are flowers physiologically sinks or faucets? Costs and correlates of water use by flowers of Polemonium viscosum. Oecologia 118:461-470.

Gokani SJ, Thaker VS (2002) Role of gibberellic acid in cotton fibre development. J. Agric. Sci. 138:255-260.

Groot SPC, Bruinsma J, Karssen CM (1987) The role of endogenous gibberellin in seed and fruit development of tomato: studies with a gibberellin-deficient mutant. Physiol. Plant. 71:184-190.

Hanson WD (1991) Seed protein content and delivery of assimilates to soybean seed embryos. Crop Sci. 31:16001604.

Hooley R (1994) Gibberellins: perception, transduction and responses. Plant Mol. Biol. 26:1529-1555.

Inglese P, Chessa I, La Mantia T, Nieddu G (1998) Evolution of endogenous gibberellins at different stages of flowering in relation to return bloom of cactus pear (Opuntia ficus-indica L Miller). Sci. Hort. 73:45-51.

Jenner CF, Ugalde TD, Aspinall D (1991) The physiology of starch and protein deposition in the endosperm of wheat. Aus. J. Plant Physiol. 18:211-226.

Kamijima O (1981) Consideration on the mechanism of expression of dwarf genes in rice plants. II. The actions of dwarf genes on cell division and cell elongation in parenchyma of internode. Jap. J. Breed. 31:302-315.

Mahouachi J, Gomez-Cadenas A, Prime-Millo E, Talon M (2005) Antagonistic changes between abscisic acid and gibberellins in citrus fruits subjected to series of different water conditions. J. Plant Growth Regul. 24:179-187. 
Matsuoka M (2003) Gibberellins signaling: How do plant cells respond to GA signals? J. Plant Growth Regul. 22:123-125.

Nakayama A, Park S, Xu Zheng-Jun, Nakajima M, Yamaguchi I (2002) Immunohistochemistry of active gibberellins and gibberellin-inducible $\alpha$-amylase in developing seeds of Morning Glory. Plant Physiol. 129:1045-1053.

Nanda KK, Dhindsa RS (1968) Effect of gibberellic acid on starch content of soybean (Glycine max L.) and its correlation with extension growth. Plant Cell Physiol. 9:423-432.

Nerd A, Mizrahi Y (1995) Reproductive biology. In: Barbera G, Inglese P, Pimienta-Barrios E (eds), Agro-Ecology, Cultivation and Uses of Cactus Pear, pp.49-57. Plant Production and Protection Paper 132, FAO, Rome.

Nitsch JP (1970) Hormonal factors in growth and development. In: Hulme AC (ed), The Biochemistry of Fruits and their Products, pp.427-472. Academic Press, London.

Pharis RP, King RW (1985) Gibberellins and reproductive development in seed plants. Annu. Rev. Plant Physiol. 36: 517-568.

Rabadia VS, Thaker VS, Singh YD (1999) Relationship between water content and growth of seed and fibre of three cotton genotypes. J. Agron. Crop Sci. 183: 255261.

Rajendrudu G, Naidu CV (1997) Effects of water stress on leaf growth and photosynthetic and transpiration rates of Tectona grandis. Biol. Plant. 40: 229-234.

Richards DE, King KE, Ait-Ali T, Harberd NP (2001) How gibberellin regulates plant growth and development: a molecular genetic analysis of gibberellin signaling. Annu. Rev. Plant Physiol. Plant Mol. Biol. 52:67-88.

Rock CD, Quatrano RS (1995) The role of hormones during seed development. In: Davies PJ (ed), Plant Hormones:
Physiology, Biochemistry and Molecular Biology, pp.671-697. Kluwer Academic Publishers, Dordrecht.

Salunkhe DK, Chavan JK, Kadam SS (1986) Pigeonpea as important food source. Crit. Rev. Food Sci. Nutr. 23:103141.

Swain SM, Reid JB, Kamiya Y (1997) Gibberellins are required for embryo growth and seed development in pea. Plant J. 12:1329-1338.

Thaker VS, Saroop S, Vaishnav PP, Singh YD (1992) Physiological and biochemical changes associated with cotton fiber development V. Acid invertase and Sugars. Acta Physiol. Plant. 14:11-18.

van Iersel MW, Oosterhuis DM, Harris WM (1994) Apoplastic water flow to cotton leaves and fruits during development. J. Exp. Bot. 45:163-167.

Villela FA (1998) Water relations and seed biology. Sci. Agric. 55:98-101.

Vlitos AJ, Meudt W (1957) Relationship between shoot apex and effect of gibberellic acid on elongation of pea stem. Nature 180:284.

Wang J, Evangelou P (1995) Metal tolerance aspects of plant cell wall and vacuole. In: Pessarakli M (ed), Handbook of Plant and Crop Physiology. pp.695-717, Marcel Dekker, New York.

Weiler EW, Wieczorek U (1981) Determination of femtomol quantities of gibberellic acid by radioimmunoassay. Planta 152:159-167.

Yeung EC, Meinke DW (1993) Embryogenesis in Angiosperms: development of the suspensor. Plant Cell 10:1371-1381.

Zhang C, Tanabe K, Tamura F, Matsumoto K, Yoshida A $(2005){ }^{13} \mathrm{C}$-photosynthate accumulation in Japanese pear fruit during the period of rapid fruit growth is limited by the strength of fruit rather than by the transport capacity of the pedicel. J. Exp. Bot. 56:2713-2719. 